\title{
Proses Berpikir Siswa dalam Menyelesaikan Masalah Matematika berdasarkan Teori Polya ditinjau dari Adversity Quotient Tipe Climber
}

\author{
Rany Widyastuti \\ ${ }^{1}$ IAIN Raden Intan Lampung; rany_2302@yahoo.com
}

Submitted : 15-07-2015, Revised : 24-09-2015, Accepted : 16-12-2015

\begin{abstract}
The process of thinking is a process that someone does in recalling the knowledge already stored in his memory for a moment used in receiving information, processing, and concluding something. Students' thinking processes in solving math problems differ from each individual, one of which is Adversity Quotient (AQ). AQ is a capability that someone has in dealing with and solve a problem. AQ consists of 3 types, namely climber, camper, and quitter. This study aims to describe the thinking process of junior high school students in solving mathematical problems based on Polya steps in terms of Adversity Quotient (AQ) climbertype. Mathematical problem solving in this research using Polya steps. This research is a qualitative descriptive research. The data collection in this research is done by questionnaire technique and job-based interview. Data validity technique used in this research is time triangulation and using reference material. Data analysis techniques used are the concept of Miles and Huberman, namely data reduction, data presentation, and conclusion. The results showed that climber students conducted assimilation thinking processes at the stage of understanding the problem, drafting a settlement plan, solving the problem according to plan, and re-examining the results.
\end{abstract}

Keywords: Adversity Quotient; Solution to problem; Thinking Process.

\begin{abstract}
Abstrak
Proses berpikir merupakan suatu proses yang dilakukan seseorang dalam mengingat kembali pengetahuan yang sudah tersimpan di dalam memorinya untuk suatu saat dipergunakan dalam menerima informasi, mengolah, dan menyimpulkan sesuatu. Proses berpikir siswa dalam menyelesaikan masalah masalah matematika berbeda setiap individunya, salah satu faktornya adalah Adversity Quotient (AQ). AQ merupakan suatu kemampuan yang dimiliki seseorang dalam menghadapi dan menyelesaikan suatu permasalahan. AQ terdiri dari 3 tipe, yaitu climber, camper, dan quitter. Penelitian ini bertujuan untuk mendeskripsikan proses berpikir siswa SMP dalam menyelesaikan masalah matematika berdasarkan langkah-langkah Polya ditinjau dari Adversity Quotient (AQ) tipe climber. Penyeleaian masalah matematika dalam penelitian ini menggunakan langkah-langkah Polya. Penelitian ini merupakan penelitian deskriptif kualitatif. Pengumpulan data dalam penelitian ini dilakukan dengan teknik angket dan wawancara berbasis tugas. Teknik keabsahan data yang digunakan pada penelitian ini adalah triangulasi waktu dan menggunakan bahan referensi. Teknik analisis data yang digunakan adalah konsep Miles dan Huberman, yaitu reduksi data, penyajian data, dan penarikan kesimpulan. Hasil penelitian menunjukkan bahwa siswa climber melakukan proses
\end{abstract}


berpikir asimilasi pada tahap memahami masalah, menyusun rencana penyelesaian, menyelesaikan masalah sesuai perencanaan, dan memeriksa kembali hasil yang telah diperoleh.

Kata Kunci : Adversity Quotient; Pemecahan Masalah; Proses Berpikir.

\section{PENDAHULUAN}

Matematika merupakan pelajaran yang terstruktur, terorganisasi, dan berjenjang, artinya antara materi yang satu dengan materi yang lainnya saling berkaitan. Dalam pembelajaran matematika, pemecahan masalah merupakan hal yang sangat penting, bahkan sebagai jantungnya matematika. Pemecahan masalah matematika dapat membuat matematika tidak kehilangan maknanya karena suatu konsep atau prinsip akan bermakna kalau dapat diaplikasikan dalam pemecahan masalah.

Menurut Ormrod (2008: 393), pemecahan masalah adalah menggunakan (yaitu mentransfer) pengetahuan dan keterampilan yang sudah ada untuk menjawab pertanyaan yang belum terjawab atau situasi yang sulit. Kita biasanya mengasosiasikan pemecahan masalah dengan matematika dan sains, namun sebenarnya pemecahan masalah itu dapat terjadi secara nyata pada semua domain konten (content domain). Pemecahan masalah merupakan pusat pembelajaran matematika. Dengan belajar memecahkan masalah maka siswa diberi banyak kesempatan untuk menghubungkan ide matematika dan untuk mengembangkan pemahaman konseptual.

Menurut Polya (1973: xvi), terdapat empat langkah yang dapat digunakan dalam pemecahan masalah, yaitu understanding the problem, devising a plan, carrying out the plan, dan looking back. Pada langkah understanding the problem atau memahami masalah, siswa harus dapat memahami masalah yang ada dengan cara menetukan dan mencari apa yang diketahui dan apa yang ditanyakan pada masalah. Pada langkah devising a plan atau menyusun rencana penyelesaian, siswa harus dapat menyusun rencana penyelesaian dari masalah yang ada berdasarkan apa yang telah diketahui dan ditanyakan pada masalah sesuai dengan langkah pertama. Pada langkah carrying out the plan atau menyelesaikan masalah sesuai perencanaan, siswa harus dapat menyelesaikan permasalahan yang ada sesuai dengan perencanaan yang telah dibuat pada langkah kedua. Pada langkah looking back atau memeriksa kembali hasil yang telah diperoleh, siswa harus dapat memeriksa kembali hasil yang telah diperolehnya, apakah jawabannya sudah benar dan sesuai dengan apa yang ditanyakan pada masalah atau belum.

Permasalahan yang mendasar dalam dunia pendidikan kita adalah rendahnya kualitas dalam proses berpikir matematika. Seorang siswa diharapkan dapat menggunakan matematika dan pola pikir matematikanya dalam kehidupan sehari-hari dan dapat mempelajari berbagai ilmu pengetahuan yang penekanannya pada penataan nalar dan pembentukan sikap siswa serta keterampilan dalam penerapan matematika. Oleh karena itu, proses berpikir dalam matematika mempunyai peranan yang penting dalam menjawab permasalahan matematika.

Piaget menyatakan bahwa ketika anak-anak berusaha membangun pemahaman mengenal dunia, otak berkembang membentuk skema (schema). Skema menurut Santrock (2009: 48) adalah suatu tindakan atau representasi mental yang mengatur pengetahuan seseorang. Skema berhubungan dengan pola tingkah laku seseorang yang merupakan 
akumulasi dari tingkah laku yang sederhana sampai yang kompleks. Piaget memberikan konsep asimilasi dan akomodasi untuk menjelaskan bagaimana anak-anak menggunakan dan menyesuaikan skema mereka. Asimilasi (assimilation) menurut Ormrod (2008: 41) merupakan proses merespons terhadap suatu objek atau peristiwa sesuai dengan skema yang telah dimiliki. Suatu informasi (pengetahuan) baru dikenalkan kepada seseorang dan pengetahuan itu cocok dengan skema yang dimilikinya maka pengetahuan itu akan diadaptasi sehingga terbentuklah pengetahuan baru. Sehingga secara teoritis, asimilasi tidak menghasilkan perubahan skemata, tetapi asimilasi mempengaruhi pertumbuhan skemata.

Akomodasi (accomodation) menurut Ormrod (2008: 41) merupakan proses merespons suatu peristiwa baru dengan memodifikasi skema yang telah ada sehingga sesuai dengan objek atau peristiwa baru, atau membentuk skema yang sama sekali baru yang sesuai dengan objek atau peristiwa yang dialami. Jika siswa mendapatkan informasi baru dan informasi tersebut agak berbeda atau sama sekali tidak cocok dengan skema yang telah ada maka akan dibentuk skema baru yang cocok dengan informasi itu. Sebaliknya, jika informasi baru itu hanya kurang sesuai dengan skema yang telah ada maka skema yang lama tersebut akan dimodifikasi sehingga cocok dengan informasi baru itu.

Proses berpikir yang baik tentunya akan membawa dampak yang baik pula pada prestasi belajar siswa. Proses berpikir siswa dapat berjalan dengan baik jika terdapat peran serta guru yang nantinya dapat membantu siswa untuk mendapatkan hasil yang baik dan benar sesuai dengan yang diinginkan. Peran serta guru tersebut misalnya bisa dilakukan dengan menanyakan kembali hasil yang telah diperoleh siswa sesuai dengan apa yang ada di pikirannya. Dengan demikian, guru akan mengetahui sampai dimana pemahaman siswa terhadap materi yang sedang diajarkan. Selain itu, dengan menanyakan kembali hasil yang telah diperoleh siswa maka guru dapat mengetahui kesalahan-kesalahan yang dilakukan siswa tersebut dalam menyelesaikan masalah matematika.

Setiap siswa dalam menyelesaikan masalah matematika memiliki cara yang berbedabeda sesuai dengan karakteristiknya masing-masing. Seseorang dapat menyelesaikan atau memecahkan masalah yang ada dengan baik apabila didukung oleh kemampuan menyelesaikan masalah yang baik pula. Kemampuan yang dimiliki seseorang untuk menguba $\mathrm{h}$ dan mengolah suatu permasalahan atau kesulitan yang terjadi dalam hidupnya dan menjadikan masalah tersebut menjadi suatu tantangan yang harus diselesaikan dengan sebaik-baiknya dikenal dengan Adversity Quotient (AQ).

Menurut Pangma, Tayraukham, dan Nuangchalem (2009):

Adversity Quotient begins its first by cognitive development. Teenagers will learn how to response to the questions to some problems. These experience of children have been developed with them since they were born which can be improved or developed, therefore, the parents propose a good care so that they will grow up with efficiency.

$\mathrm{AQ}$ dimulai pertama kali melalui perkembangan kognitif. Para remaja akan belajar bagaimana merespon atau menyelesaikan beberapa pertanyaan dari masalah yang ada. Pengalaman dari anak-anak telah dimulai perkembangannya sejak mereka lahir dimana mereka dapat memperbaiki atau mengembangkannya. Oleh karena itu, para orang tua dapat memperhatikan dengan baik anak-anak mereka sehingga anak-anak tersebut dapat tumbuh dengan baik. 
AQ menurut Stoltz (2000: 8) dapat menjadi indikator untuk melihat seberapa kuatkah seseorang dapat terus bertahan dalam suatu masalah yang sedang dihadapinya. Selain itu juga, AQ dapat menjadi indikator untuk melihat bagaimanakah seseorang dapat mengatasi masalahnya, apakah mereka dapat keluar sebagai pemenang, ataukah mereka mundur di tengah jalan, atau bahkan tidak mau menerima tantangan sedikit pun.

Pada $\mathrm{AQ}$, kelompok atau tipe seseorang dapat dibagi menjadi tiga tipe, yaitu quitters, campers, dan climbers. Quitters merupakan sekelompok orang yang berhenti di tengah pendakian. Mereka mudah putus asa, dan mudah menyerah, cenderung pasif, dan tidak bergairah untuk mencapai puncak keberhasilan. Campers sekurang-kurangnya telah menanggapi tantangan yang ada. Campers tidak mencapai puncak dan mudah puas dengan apa yang sudah dicapai. Mereka masih mengusahakan terpenuhinya kebutuhan rasa aman dan keamanan serta kebersamaan, serta masih bisa melihat dan merasakan tantangan. Climbers merupakan sekelompok orang yang selalu berupaya mencapai puncak kesuksesan, siap menghadapi rintangan yang ada, dan selalu membangkitkan dirinya pada kesuksesan. Climbers memang menantang perubahan-perubahan. Climbers akan terus berusaha untuk menggapai kesuksesan tanpa menghiraukan latar belakang, keuntungan, atau kerugian, nasib buruk atau nasib baik.

Menurut Yansen Marpaung (2005: 6), kelompok quitters memiliki sikap dan motivasi yang kurang kuat dalam belajar. Kelompok campers memiliki sikap dan motivasi sedang dalam belajar. Kelompok climbers memiliki sikap dan motivasi tinggi dalam belajar. Sikap dan motivasi tersebut menimbulkan dorongan-dorongan yang sesuai dalam diri setiap siswa. Dengan demikian seorang guru memiliki tugas yang sangat penting dalam proses pembelajaran, yaitu seorang guru harus bisa menumbuhkan sikap dan motivasi siswa selama pembelajaran berlangsung. Pada penelitian ini, peneliti akan meneliti AQ khusus pada tipe climbersaja.

Indikator pemecahan masalah matematika berdasarkan langkah-langkah Polya disajikan pada tabel berikut ini.

Tabel 1. Indikator Pemecahan Masalah Matematika

\begin{tabular}{|c|c|c|}
\hline Langkah & Pemecahan Masalah & Indikator \\
\hline 1 & Memahami masalah & $\begin{array}{l}\text { 1. Siswa dapat menentukan hal yang diketahui } \\
\text { dari soal. } \\
\text { 2. Siswa dapat menentukan hal yang } \\
\text { ditanyakan dari soal. }\end{array}$ \\
\hline 2 & $\begin{array}{l}\text { Menyusun } \\
\text { penyelesaiannya }\end{array}$ & $\begin{array}{l}\text { 1. Siswa dapat menentukan syarat lain yang } \\
\text { tidak diketahui pada soal seperti rumus atau } \\
\text { informasi lainnya jika memang ada. } \\
\text { 2. Siswa dapat menggunakan semua informasi } \\
\text { yang ada pada soal. } \\
\text { 3. Siswa dapat membuat rencana atau langkah- } \\
\text { langkah penyelesaian dari soal yang } \\
\text { diberikan. }\end{array}$ \\
\hline
\end{tabular}




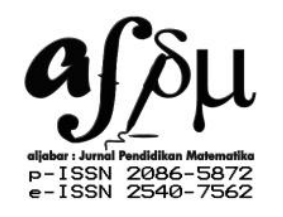

Al-Jabar: Jurnal Pendidikan Matematika

Vol. 6, No. 2, 2015, Hal 183 - 193

$3 \quad$ Menyelesaikan masalah sesuai perencanaan

1. Siswa dapat menyelesaikan soal yang ada sesuai dengan langkah-langkah yang telah dibuat sejak awal.

2. Siswa dapat menjawab soal dengan tepat.

$4 \quad$ Memeriksa kembali hasil yang

1. Siswa dapat memeriksa kembali jawaban telah diperoleh yang telah diperoleh dengan menggunakan cara atau langkah yang benar.

2. Siswa dapat meyakini kebenaran dari jawaban yang telah dibuat.

\section{METODE PENELITIAN}

Penelitian ini merupakan penelitian deskriptif kualitatif. Pemilihan subjek penelitian dilakukan dengan menggunakan gabungan teknik stratified sampling dan purposive sampling. Untuk mengetahui Adversity Quotient (AQ) dari masing-masing siswa maka diberikan angket $A Q$ yang merujuk pada teori Paul G. Stoltz dengan melakukan perbaikan kalimat pada angket yang disesuaikan dengan tingkat berpikir siswa SMP. Subjek dalam penelitian ini adalah siswa kelas VIII SMP Negeri yang memiliki AQ dengan tipe climber.

Instrumen utama dalam penelitian ini adalah peneliti sendiri. Instrumen pendukungnya adalah instrumen penggolongan tipe $A Q$, instrumen pedoman wawancara yang didasarkan pada langkah-langkah Polya, dan instrumen lembar tugas pemecahan masalah matematika. Sumber data diperoleh melalui siswa yang terpilih menjadi subjek penelitian. Pengumpulan data dilakukan dengan teknik angket dan wawancara berbasis tugas. Uji kredibilitas data atau kepercayaan terhadap data hasil penelitian dilakukan dengan triangulasi waktu dan menggunakan bahan referensi. Wawancara berbasis tugas dilakukan untuk mengetahui proses berpikir siswa SMP tipe climber dalam menyelesaikan masalah matematika berdasarkan langkah-langkah Polya. Teknik analisis data yang digunakan adalah menggunakan konsep Miles dan Huberman, yaitu reduksi data, penyajian data, dan penarikan kesimpulan. (Sugiyono, 2011: 337)

\section{HASIL PENELITIAN DAN PEMBAHASAN}

\section{Proses Berpikir Siswa Tahap Memahami Masalah}

Cuplikan dialog antara peneliti dan siswa climber (CL) pada tahap memahami masalah untuk tes pertama adalah sebagai berikut.

$\mathrm{P}$ : Coba baca masalah yang pertama ini dalam hati dulu.

$\mathrm{CL}$ : (membaca soal) (menganggukkan kepala)

$\mathrm{P}$ : Sudah?

$\mathrm{CL}$ : (menganggukkan kepala)

$\mathrm{P}$ : Dari masalah yang pertama ini, informasi apa sih yang diperoleh dari soal?

$\mathrm{CL}$ : Ibu Susi mempunyai dua orang anak yang bernama Fatin dan Arrafi. Umur Araffi sekarang 4 tahun kurangnya dari umur Fatin. Jumlah umur mereka sekarang adalah 24 tahun.

P : Itu sebagai apanya? 
$\mathrm{CL}$ : Ehm...sebagai yang diketahuinya.

$\mathrm{P}$ : Selanjutnya?

$\mathrm{CL}$ : Ditanya.

$\mathrm{P}$ : Ditanyanya?

$\mathrm{CL}$ : Berapa umur mereka saat ini.

$\mathrm{P}$ : Yakin gak dengan jawabannya?

$\mathrm{CL}$ : Yakin.

$\mathrm{P} \quad$ : Kalau yakin coba tulis di bagian memahami masalah apa yang kamu jelaskan tadi.

$\mathrm{CL}$ : (menuliskan jawabannya di lembar jawaban)

Qiker: Ibu susi mempunyai 2 anaki yaitu fatin \& Araffi

Umur Araffi 4 tabun teurangnya dari umur fatin.

- Jumlan umur meretra $=24$ tahun

Dit: Umur fatin s Araffi.. ?

Cuplikan dialog antara peneliti dan siswa climber (CL) pada tahap memahami masalah untuk tes kedua adalah sebagai berikut.

$P \quad$ : coba kamu baca soalnya

$\mathrm{CL}$ : (mulai membaca soal) Juwita merupakan anak dari Ayah Luhan. Sekarang umur Ayah Luhan dan umur Juwita adalah 41 tahun dan 9 tahun. Berapa tahun lagikah umur ayah Luhan akan menjadi tiga kali umur Juwita?

$\mathrm{P} \quad$ : Informasi apa yang bisa kamu dapat dari soal ini?

$\mathrm{CL}$ : Umur Ayah Luhan dan umur Juwita adalah 41 tahun dan 9 tahun.

$\mathrm{P}$ : Udah itu aja?

$\mathrm{CL}:$ : lya.

$\mathrm{P} \quad$ : Terus yang ditanya apa?

$\mathrm{CL}$ : Berapa tahun lagikah umur ayah Luhan akan menjadi tiga kali umur Juwita?

$\mathrm{P}$ : Sudah. Kamu tidak memerlukan informasi tambahan lagi untuk menyelesaikan soal ini?

$\mathrm{CL}$ : Gak Insya Allah.

$\mathrm{P}$ : Silahkan kamu tulis dilembar jawaban ya.

$\mathrm{CL}$ : (mulai menuliskan jawaban pada lembar jawaban)

Diket: Umur gyah $=41$ tahur

11 Jiwita $=9$ talhun

dit: Berapa tahun lago umur ajgah luhan atean menadi $3 \times$ umur juwita?

Berdasarkan hasil wawancara dan lembar jawaban yang telah diberikan oleh siswa CL dapat diketahui bahwa siswa CL dapat mengidentifikasi apa yang diketahui dan apa yang ditanyakan pada masalah dengan tepat dan benar, baik untuk tes pertama maupun kedua. Siswa CL dapat menyebutkan dan menuliskan dengan lancar dan benar hal-hal apa saja yang diketahui dan yang ditanyakan pada masalah untuk masalah pada tes pertama maupun kedua. Dari penjelasan tersebut dapat diketahui bahwa siswa CL dapat mengitegrasikan secara langsung informasi atau pengetahuan barunya ke dalam skema yang ada dipikirannya. Dengan demikian dapat dikatakan bahwa siswa CL melakukan proses berpikir asimilasi dalam memahami masalah. 


\section{Proses Berpikir Siswa Tahap Menyusun Rencana Penyelesaiannya}

Cuplikan dialog antara peneliti dan siswa climber $(\mathrm{CL})$ pada tahap menyusun rencana penyelesaian untuk tes pertama adalah sebagai berikut.

$\mathrm{P}$ : Sekarang setelah kamu yakin. Cara atau langkah apa yang akan kamu pakai untuk menyelesaikan masalah matematika?

$\mathrm{CL}$ : Ini kan persamaan linier satu variabel.

$P$ : Iya.. terus bagaimana?

$\mathrm{CL}$ : Dipermisalkan.

$\mathrm{P} \quad$ : Apa yang dipermisalkan?

$\mathrm{CL}$ : Umur fatin sama umur araffinya (sembari kembali melihat soal)

$\mathrm{P}$ : Terus?

$\mathrm{CL}:$ Ehm... (berpikir sebentar)

Fatinnya $x$, berarti araffi nya $x-4$ ya.

$\mathrm{P} \quad$ : Kenapa bisa $\mathrm{x}-4$ ?

$\mathrm{CL}$ : (melihat kebagian diketahui) Kan diketahui umur arrafi 4th kurangnya dari umur Fatin.

$\mathrm{P}$ : Yakin?

$\mathrm{CL}:$ : lya...

$\mathrm{P} \quad$ : Kalau yakin coba tuliskan permisalannya.

$\mathrm{CL}$ : (menuliskan jawaban pada lembar jawaban)

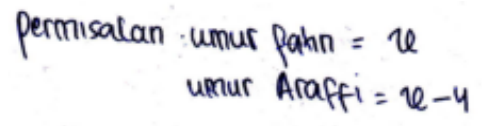

Cuplikan dialog antara peneliti dan siswa climber $(\mathrm{CL})$ pada tahap menyusun rencana penyelesaian untuk tes kedua adalah sebagai berikut.

$\mathrm{P} \quad$ : Cara atau langkah pertama kamu untuk mengerjakan soal ini bagaimana?

$\mathrm{CL}$ : (melihat soal) Umur ayah sama umur juwita nya dipermisalin ditambah $x$.

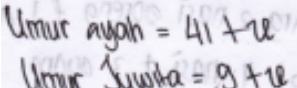

Umur Suwta $=9+v$

$\mathrm{P} \quad$ : Kenapa bisa ditambah $\mathrm{x}$ ?

$\mathrm{CL}$ : Karenakan yang ditanya berapa tahun lagikah..

$\mathrm{P}$ : Selanjutnya?

$\mathrm{CL}$ : (membaca soal kembali) Umur ayah sama dengan $3 x$ umur juwita.

$\mathrm{P} \quad$ : Tiga kali umur juwita itu didapat darimana?

$\mathrm{CL}$ : Dari sini. (menunjuk ke arah ditanya pd lembar jawaban)

$\mathrm{P}$ : Yakin?

$\mathrm{CL}$ : (mengangguk)

Berdasarkan hasil wawancara dan lembar jawaban yang telah diberikan oleh siswa $\mathrm{CL}$ dapat diketahui bahwa siswa CL dapat menentukan langkah atau cara apa yang akan digunakan untuk menyelesaikan masalah, baik untuk tes pertama maupun tes kedua. Siswa $\mathrm{CL}$ akan terlebih dahulu mengubah kalimat matematika yang ada pada soal menjadi model matematika sehingga membentuk sistem persamaan linear satu variabel untuk tes pertama 
maupun tes kedua. Siswa $\mathrm{CL}$ dapat menjelaskan dan menuliskan dengan benar dan lancar persamaan tersebut. Dari penjelasan tersebut dapat diketahui bahwa siswa CL dapat mengintegrasikan secara langsung informasi atau pengetahuan barunya ke dalam skema yang ada dipikirannya. Dengan demikian dapat dikatakan bahwa siswa CL melakukan proses berpikir asimilasi dalam menyusun rencana penyelesaiannya.

\section{Proses Berpikir Siswa Tahap Menyelesaikan Masalah Sesuai Perencanaan}

Cuplikan dialog antara peneliti dan siswa climber $(\mathrm{CL})$ pada tahap menyelesaikan masalah sesuai perencanaan untuk tes pertama adalah sebagai berikut.

$P$ : Kalau yakin coba diselesaikan masalah ini. Mau dicoba dicoretan dulu atau mau langsung di lembar jawaban?

$\mathrm{CL}$ : Langsung aja. (mulai mengerjakan)

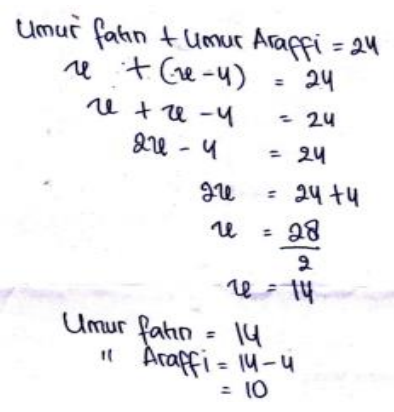

$P \quad:$ Sudah?

$\mathrm{CL}$ : (menganggukkan kepala)

$\mathrm{P}$ : Sudah didapat jawabannya?

$\mathrm{CL}: x$ nya 14.

$\mathrm{P}$ : Dapat dari mana?

$\mathrm{CL}$ : Ini dari sini. (menunjuk ke bagian proses penyelesaian)

$\mathrm{P} \quad$ : $\mathrm{x}$ itu sebagai apanya?

$\mathrm{CL}$ : Fatinnya.

$\mathrm{P} \quad$ : Berarti umur arrafi berapa?

$\mathrm{CL}$ : (melihat ke arah jawaban) $x-4$, jadi umur arrafi 10 tahun.

$P$ : Yakin?

$\mathrm{CL}:$ : lya.

$\mathrm{P}$ : Tidak mau berubah?

$\mathrm{CL}$ : Gakah.

Cuplikan dialog antara peneliti dan siswa climber $(\mathrm{CL})$ pada tahap menyelesaikan masalah sesuai perencanaan untuk tes kedua adalah sebagai berikut.

$\mathrm{CL}$ : Kayak gini mba? (berhenti sejenak dan melihat hasil jawaban yang telah diperoleh)

$\mathrm{P} \quad$ : Kerjakan dulu saja.

$\mathrm{CL}:$ (diam)

$\mathrm{P}$ : Gimana? Yakin gak kamu sama jawaban kamu?

$\mathrm{CL}:$ (melihat ke arah jawaban)

$\mathrm{P} \quad$ : Kamu mau nyari apa nya?

$\mathrm{CL}$ : Mau nyari berapa tahun lagi itu.

$\mathrm{P}$ : Nyari $\mathrm{x}$ nya? 
$\mathrm{CL}$ : Iya. (melanjutkan menuliskan jawabannya pada lembar jawaban)

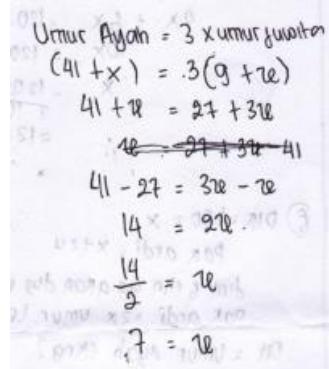

$\mathrm{P} \quad$ : Jadi yakin gak sama jawabannya?

$\mathrm{CL}$ : (melihat kelembar jawaban) dapet $x$ nya 7.

$\mathrm{P} \quad$ : Ini kenapa dicoret? (menunjuk ke arah $\mathrm{x}=27+3 \mathrm{x}-41$ )

$\mathrm{CL}$ : Salah, gak jadi. (sambil tersenyum)

$\mathrm{P} \quad$ : Oh gak jadi. Yakin dengan jawaban kamu?

CL : lya yakin.

Berdasarkan hasil wawancara dan lembar jawaban yang diberikan oleh siswa CL dapat diketahui bahwa siswa $C L$ dapat menyelesaikan masalah sesuai dengan perencanaan yang telah dibuat, baik untuk tes pertama maupun tes kedua. Siswa CL menyelesaikan masalah yang ada melalui permisalan yang telah dibuatnya pada langkah menyusun rencana penyelesaian. Siswa dapat menyelesaikan masalah yang ada dengan benar dan algoritma perhitungan yang dilakukan juga benar pada tes pertama dan tes kedua. Dari penjelasan tersebut dapat diketahui bahwa siswa CL dapat mengintegrasikan secara langsung informasi atau pengetahuan barunya ke dalam skema yang ada di pikirannya. Dengan demikian dapat dikatakan bahwa siswa CL melakukan proses berpikir asimilasi dalam menyelesaikan masalah sesuai dengan perencanaan yang telah dibuat.

Proses Berpikir Siswa Tahap Memeriksa Kembali Hasil yang Telah Diperoleh

Cuplikan dialog antara peneliti dan siswa climber (CL) pada tahap memeriksa kembali hasil yang telah diperoleh untuk tes pertama adalah sebagai berikut.

$\mathrm{P} \quad$ : Terus bagaimana kamu bisa yakin kalo jawaban kamu benar?

$\mathrm{CL}$ : Kalau dijumlahin ya jadi 24 tahun.

$\mathrm{P}$ : Apanya yang dijumlahkan?

$\mathrm{CL}$ : Umur arrafi dan umur fatin kalau dijumlahin 24.

$P \quad$ : Coba kamu buktikan.

$\mathrm{CL}$ : (mulai menghitung) Sudah.

Umur Araffi tumur fahn $=14$ +10

$\mathrm{P} \quad$ : Yakin dengan yang kamu tuliskan?

$\mathrm{CL}$ : Yakin.

$\mathrm{P}$ : Jadi kamu yakin bahwa umur arrafi 14 tahun dan umur fatin 10 tahun?

$\mathrm{CL}$ : Yakin.

$\mathrm{P}$ : Selain ini, ada cara lain gak sih untuk bisa memeriksanya?

$\mathrm{CL}$ : Sudah aja.

$\mathrm{P} \quad$ : Setau kamu caranya seperti ini saja?

$\mathrm{CL}:$ : lya. 
Cuplikan dialog antara peneliti dan siswa climber $(\mathrm{CL})$ pada tahap memeriksa kembali hasil yang telah diperoleh untuk tes kedua adalah sebagai berikut.

$\mathrm{P} \quad$ : Bagaimana cara kamu yakin kalo jawaban $\mathrm{x}$ kamu itu benar?

$\mathrm{CL}$ : Dimasukin kesini (menunjuk kearah $41+x$ dan $9+x$ )

P : Coba kamu kerjakan.

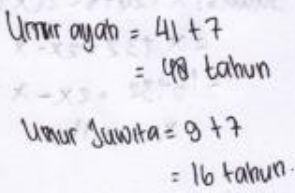

$\mathrm{CL}$ : Nih didapat umur ayah 48th dan umur juwita 16 tahun.

$\mathrm{P}$ : Terus kenapa kamu yakin jawaban kamu benar?

$\mathrm{CL}:$ (melihat kearah jawaban)

(mencoba mengkalikan 16 dengan 3)

Karena umur juwita 3 kali umur ayah.

$\mathrm{P}$ : Yakin?

$\mathrm{CL}:$ :lya.

$\mathrm{P}$ : Gak mau berubah jawabannya?

$\mathrm{CL}$ : Gak.

Berdasarkan hasil wawancara dan lembar jawaban yang diberikan oleh siswa CL dapat diketahui bahwa siswa CL dapat meyakini kebenaran dari hasil yang telah diperoleh, baik pada tes pertama maupun tes kedua. Siswa CL dapat menentukan cara atau langkah apa yang akan digunakan untuk memeriksa hasil yang telah diperoleh pada tes pertama dan tes kedua, yaitu dengan cara mengembalikan hasil yang telah diperoleh ke hal yang diketahui pada masalah. Setelah dilakukan pemeriksaan terhadap hasilnya, ternyata hasil yang telah diperoleh siswa pada langkah menyelesaikan masalah tersebut benar dan telah sesuai dengan hal yang diketahui pada masalah. Dari penjelasan tersebut dapat diketahui bahwa siswa CL dapat mengintegrasikan secara langsung informasi atau pengetahuan barunya ke dalam skema yang ada di pikirannya. Dengan demikian dapat dikatakan bahwa siswa CL melakukan proses berpikir asimilasi dalam memeriksa kembali hasil yang telah diperolehnya.

Berdasarkan penjelasan yang telah diberikan dapat diketahui bahwa siswa CL dengan tipe climber melakukan proses berpikir asimilasi baik pada tahap memahami masalah, menyusun rencana penyelesaian, menyelesaikan masalah sesuai perencanaan, maupun memeriksa kembali hasil yang telah diperoleh. Dari hasil wawancara yang telah dilakukan terlihat bahwa selama siswa menyelesaikan masalah, siswa tidak pernah mengeluh terhadap masalah yang diberikan. Siswa tidak begitu saja meyakini kebenaran dari hasil yang telah diperolehnya sebelum siswa melakukan pemeriksaan kembali terhadap hasilnya tersebut. Hal ini sesuai dengan teori dari Stoltz (2000) yang mengatakan bahwa orang dengan tipe climber adalah tipe orang yang selalu berusaha mencapai puncak kesuksesan, siap menghadapi rintangan yang ada, dan selalu membangkitkan dirinya pada kesusksesan. Pendapat yang serupa juga dikemukakan oleh Yansen Marpaung (2005) yang mengatakan bahwa orang dengan tipe climber memiliki sikap dan motivasi yang tinggi dalam belajar. 


\section{SIMPULAN DAN SARAN}

Berdasarkan hasil analisis dan pembahasan yang telah dijelaskan maka diperoleh kesimpulan bahwa:

1. Siswa SMP tipe climber melakukan proses berpikir asimilasi dalam memahami masalah.

2. Siswa SMP tipe climber melakukan proses berpikir asimilasi dalam menyusun rencana penyelesaian.

3. Siswa SMP tipe climber melakukan proses berpikir asimilasi dalam menyelesaikan masalah sesuai perencanaan.

4. Siswa SMP tipe climbermelakukan proses berpikir asimilasi dalam memeriksa kembali hasil yang telah diperoleh.

\section{DAFTAR PUSTAKA}

Ormrod, J. E. (2008). Psikologi Pendidikan (Membantu Siswa Tumbuh dan Berkembang). Penerjemah: Amitya Kumara. Jakarta: Erlangga.

Pangma, R., Tayraukham, S., dan Nuangchalem, P. (2009). Causal Factors Influencing Adversity Quotient of Twelfth Grade and Third Year Vocational Students. Journal of Social Sciences. 5 (4): 466-470.

Polya, G. (1973). How To Solve It (A New Aspect of Mathematical Method). New Jersey: Priceton University Press.

Santrock, J. W. (2009). Psikologi Pendidikan (Educational Psychology). Penerjemah: Diana Angelica. Jakarta: Salemba Humanika.

Stoltz, P. G. (2000). Adversity Quotient (Mengubah Hambatan Menjadi Peluang). Jakarta: Gramedia Widiasarana Indonesia.

Sugiyono. (2011). Metode Penelitian Pendidikan (Pendekatan Kuantitatif, Kualitatif, dan R \& D). Bandung: Alfabeta.

Yansen Marpaung. (2005). Karakteristik PMRI (Pendidikan Matematika Realistik Indonesia). Makalah Disajikan pada Seminar Rumpun MIPA di Universitas Sanata Dharma Yogyakarta, Yogyakarta, tanggal 30 November 2005. 